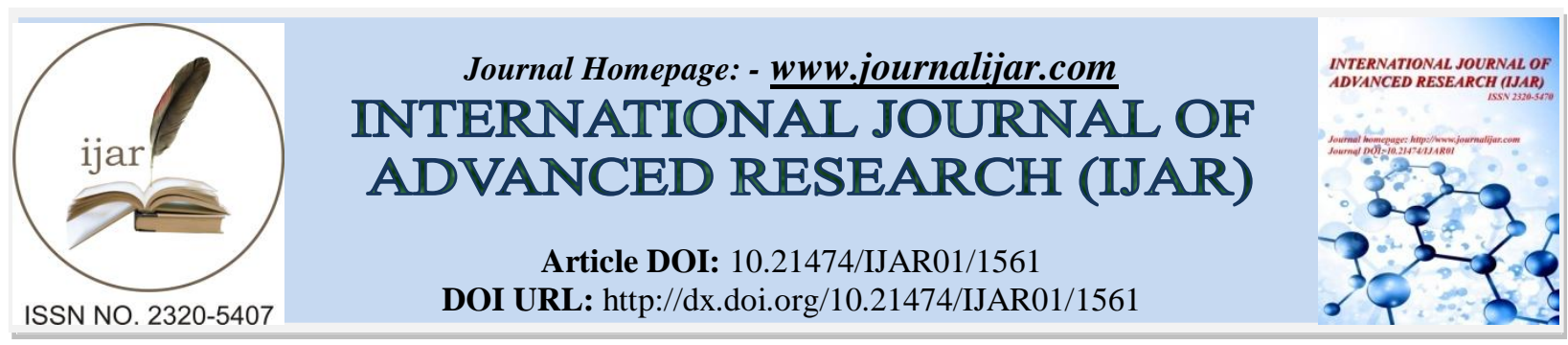

RESEARCH ARTICLE

\title{
NARRATIVE OF POLITICAL VIOLENCE AND SOCIAL REALITIES: A STUDY OF TEMSULA AO'S THESE HILLS CALLED HOME: STORIES FROM A WAR ZONE.
}

Khumanthem Gunibala Devi (Research Scholar) and Dr. Sangeeta Laishram (Asst. Professor) Department of Humanities and Social Sciences, National Institute of Technology, Manipur- 795001.

\section{Manuscript Info}

Manuscript History

Received: 14 July 2016

Final Accepted: 16 August 2016

Published: September 2016

Key words:-

Conflicts, violence, social issues, politics, identity

\section{Abstract}

The purpose of the paper is to explore the pattern of political violence and social realities in the particular state of Northeast India- Nagaland. The paper attempts to describe how the Naga struggle with the armed forces to occupy a separate political entity and how they search their identity and peace in the midst of violence and terror. It makes an attempt to give the idea that how the trauma of violence and unstable political conditions of a state bring the fragility of human conditions. Focusing on Temsula Ao's short stories collection entitled These Hills Called Home: Stories from a war zone, the paper discusses the social realities of Nagaland during insurgency and counter-insurgency period. The stories depict common people who are victimized by the conflicts, violence and politics of the state and about the violation of human rights by different militant organizations and security forces. The social and cultural milieu forms the central focus of Temsula Ao's short stories.

Copy Right, IJAR, 2016,. All rights reserved.

\section{Introduction:-}

The state Nagaland is bounded by Manipur in the south, Assam in the north and north-west, Arunachal Pradesh in the north-east and Myanmar in the east. For many decades, the state remained quite isolated and separated from mainland India. "Cut off from the rest of the world at the eastern hem of the Himalayas, it is home to nearly two million people from some sixteen Tibetan-Burmese tribes who have been fighting a remote and rarely reported war for independence from India, on and off, since the early 1950s". (Glancey 1) "For many of them Nagaland, which has existed as a state only since 1963, is an Indian fabrication that fails to recognize their nationhood: a fragmentation of their natural homeland by politically expedient boundaries." (Glancey 1) The history of Nagaland from a district to state is full of political upheavals, violence and bloodshed. The Nagas had to endure the political unrest and armed conflicts to attain a separate political entity. The war between the Naga freedom fighters and armed personnel causes a great loss of innocent lives and properties in the state. The memory of the political experience of the past is still haunting and hurting the mind of the people because the agony of the suffering reached its zenith during the days of armed struggle. To be precise, the historical development of Nagaland has been quite tumultuous.

After India's independence and creation of Nagaland state, there is a great change in the pace of social, economic, and political but the changes become a hindrance to the economic growth of the state and its people due to the upheavals in the political situation. This stalking situation imposes the writers to write about their immediate surroundings in the region. Most of the writings from Northeast convey their feelings and sentiments about various 
aspects of nationalist ideals. The Northeast writers are tagged as social writers and this tag comes with added responsibility. They cannot and do not remain complacent to the social and political ethos of the people and their land. Commenting on the features of Northeast literature and its theme, Tilottama Misra opines: "violence features as a recurrent theme because the story of violence seems to be never-ending one in this region and yet people have not learnt 'to live with it', as they are expected to do by the distant centres of power."(xxi) In this context, a writer, Manash Pratim Borah also states: "...literature written in this region is a camouflaged representation in fictional form of social reality representing typical North-Eastern socio-political experiences and violence along with strong commentaries of socially committed writers. The literature of Northeast India, which has achieved a lot of ascendancy in the last few decades, has not only used violence and socio-political experiences as thematic interest but also foregrounded them as a recurring motif." (15) He further remarks that "To have a comprehensive idea about violence and socio-political experiences of Northeast, the best way to ponder over those narratives which are not simply historical documentations of those violence and experiences but revealing the true spirit of literature, the imaginative minds of the region are always found to be busy in searching therapeutic remedies of those problems for the sake of exegesis of peace and restoration of lost order and stability."(15) For the Northeast writers, their literatures serve as a platform where they can express their trauma and sufferings, either in vernacular or in English, to assert identity and peace in the midst of violence. Their voice is the collective voice of people who had been exploited, neglected and alienated in their own villages. Writers become the social, cultural and political antenna of their people and their land.

Temsula Ao is, undoubtedly, a renowned modern Northeast writer emerging from the state of Nagaland. She has published five volumes of poems namely Songs That Tell (1988), Songs That Try To Say (1992), Songs Of Many Moods (1995), Songs From Here And There (2003), and Songs From Other Life (2007). She has also published two collections of short stories entitled These Hills Called Home: Stories from a War Zone (2006) and Laburnum For My Head (2009). A critical book on Henry James and a memoir had also been published. Her writing is quite significant because she is not hesitant to recreate the social and political upheavals of Nagaland in her literary world. For her admirable creative works, she received Padma Shri, Sahitya Akademi and even the state Meghalaya rewarded her with governor's gold medal award. In These Hills Called Home, Ao gives a picture of Nagaland where the common people are trapped in an atmosphere of violence and conflicts. It deals with the Naga insurgency and its consequences. Most of the time, the Nagas are shocked by the brutal armed forces and militancy. She narrates exactly the historical and political growth of the Nagas without any idealization, but rather narrates the political strife and turmoil of the land. And here comes the integrity of a great writer. She writes about Naga's quest for separate political status and how the villagers survive in such a conflict prone area. The agony of suffering resulting from the crisis of politics and identity in the region had engraved in her mind for decades and she could not hold still and so with the help of memory she poured the realities of Nagas at the time of insurgency in her creative works.

Among the ten stories, "The Jungle Major" is the first story that narrates the spreading of militancy and its consequences. After marriage, Punaba, the protagonist, started joining in the underground activities. The meeting of Punaba and his wife was occasional as Punaba was forced to live in the jungle for he was a member of the underground group. But his wife Kathila preferred to remain silent than to face the consequences of confronting with the army. During insurgency period, to encounter with the army personnel in such a situation invites loss of innocent lives and most of the time, dignity. This scenario is vividly portrayed in the story:

Some villagers, to which the underground leaders belonged, were severely punished. The houses were ransacked by the security forces, the grain in their barns was burnt and the people themselves were herded into camps away from the village and kept in virtual imprisonment inside areas fenced in by bamboo stockades. This form of group incarceration was the infamous 'grouping' of villages which the Nagas hated and dreaded even more than bullets. Numerous stories proliferated of women being molested by the security forces and the obstinate ones who refused to give information being severely beaten; not only that, sometimes they would be hung upside down subjected to unspeakable tortures like chilli powder being rammed into their extremities. (Ao 3)

In one of his meeting with his wife, Indian army reached his home and Punaba had no chance of escaping but it was Kathila's presence of mind that saved Punaba and the entire people of the village from certain death and destruction.

In the story "The Last Song", Ao describes a young girl, Apenyo, who was brutally gang-raped by the Indian army during the chaos and confusion period of Nagaland. It was the women who suffered a lot in those days. The story powerfully depicts how women and children are treated in a conflicting political situation. It is seen when the young 
captain and his group operated the villages. During the operation, Apenyo became a victim to the Army captain and "he grabbed Apenyo by the hair and with a bemused look on his face dragged her away from the crowd towards the old church building." (28) Ao further carries the insane act of armed forces in the story as: "the young captain was raping Apenyo while a few soldiers were watching the act and seemed to be waiting for their turn" (28) Thus, women become a victim and a prey to the armed personnel during insurgency and counter-insurgency period and the traumatic phase undergone by the women remains as a mental stigma throughout their lives.

In another story "The Curfew Man", Ao narrates how innocent villagers became a captive in their own village. Satemba was once a constable in the Assam police. But after he left the job due to his broken knee, he became an informer of the army but as an informer too he could not find peace. There was always a tussle between his head and heart. The chance of encounter with a stranger, most likely of the underground, further strengthened his mental agony. The protagonist was caught between the two forces: the underground forces and armed forces and was searching his identity in the midst of violence. From the story, it is clear that it is very hard to survive for the young male Nagas in their own villages and they are pushed in a situation where they cannot produce even their own identity and status. Thus, Ao remarkably presents the chaos and confusion of the young Nagas in the story. When Satemba left that thankless job, he felt quite relieved. This shows that almost all the Nagas did not willingly join and help the armed forces but it was some unavoidable circumstances which impelled them to join either in the armed forces or underground group. "The Night" is a tale describing the fate of a girl whom the society despised for her illegitimate child. Imnala got pregnant and the man disappeared for he had to train himself as a soldier in China to join the underground army. Thus, the story portrays how women have continued to exist without protection from male in a conflicting political region.

"An Old Man Remembers" tells the story of Shashi and Imli who were made soldiers and ended their life at jungle. Their life was painful, pathetic and heart-touching. The bitterness of memory of the life of jungle haunted their mind almost all the time. The terrific life of the jungle is vividly drawn in the story as: "By the time when we reached the forest, away from the mayhem in the village, it was already dark. We were hungry, we were cold, but most of all were terrified, not knowing where we were heading. The eerie jungle sounds were beginning to grow in volume, which only added to our fear." (Ao 99) Situations and circumstances compelled Shashi and Imli to involve in the underground group. It is evident in their conversation as: "soldiers we were made into and that's what we resolved to remain." (Ao 101) As an underground army, they also committed brutal crimes but at the same time they repented for their acts. When they felt desperate and tried to flee from the jungle life, they were shocked as their village was totally shattered. Many villagers took shelter in the forest at west end of the village where the forest was at one time considered to be the home of spirits. Therefore, the story narrates the conflicting situation and the violation of the region during the days of struggle between the Naga underground and armed forces.

To conclude, we may say that Temsula Ao tries to fulfill her inner urge to communicate with the readers about the turbulent history of Nagaland which is incorporated with various social issues related to Naga freedom struggle, violence, identity crisis and political unrest. In her narrative, she portrays ordinary people who had experienced violence and how they negotiate power and forces to gain a unique political status. The important aspect of the book is insurgency and she gives a picture of Nagaland afflicted by militancy and armed forces. Except a limited number of stories, most of the stories depict the ruthless devastation caused by militancy and armed forces which impart nothing but battered the common people by the rapidly changing social, political, economic and even cultural scenario. In the preface, "Lest We Forget", she writes "...what the story are trying to say is that in such conflicts, there is no winners, only victims and the trauma goes beyond the realm of just the physical maiming and loss of lifetheir very humanity is assaulted and violated, and the onslaught leaves the survivors scarred in mind and soul." (Ao $\mathrm{x}$ ) Thus, the narrative delicately reveals the different kinds of violence and socio-political experiences that are physically and psychologically compelling the people living in the region to lead a life of trauma. 


\section{References:-}

1. Ao, Temsula. These Hills Called Home: Stories from a War Zone. New Delhi: Zubaan Books, 2006. Print.

2. Borah, Manash Pratim. Narratives of Violence and Northeastern Socio-political Experiences: A reading of Select Fictional Writings from Northeast India. Ethnicity, Identity and Literature: Reading Literatures from North East India. Guwahati: DVS Publishers, 2013. 13-40. Print

3. Das, Nigamananda. Ed. Matrix of Redemption: Contemporary Multi-Ethnic English Literature from North East India. New Delhi: Adhayayan Publishers and Distributors, 2011. Print.

4. Glancey, Jonathan. Introduction. Nagaland: A Journey to India's Forgotten Frontier, Faber and Faber, England, 2011. 1-10. Print.

5. Mishra, Tilotama. Ed. Introduction. The Oxford Anthology of Writings from North-East India: Poetry and Essays. New Delhi: Oxford University Press, 2011. xiii-xxxii. Print.

6. Singh, Chandrika. The Naga Society. New Delhi: Manas Publications, 2012. Print.

7. Zama, Margaret Ch. Ed. Emerging Literatures from Northeast India: The Dynamics of Culture, Society and Identity. New Delhi: Sage Publication, 2013. Print. 